\title{
A scoping review of the peer-led team learning to learner-participants and peer leaders in STEM courses
}

Guden, Jester Mark

Visayas State University (Main Campus), Philippines (jestermarkguden@gmail.com)

Bellen, Joy A. $\$

Visayas State University (Main Campus), Philippines (joy.bellen@vsu.edu.ph)

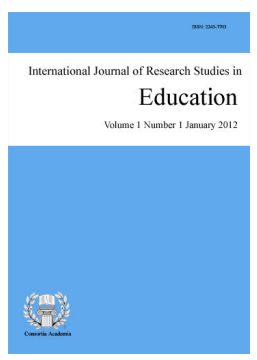

ISSN: $2243-7703$ Online ISSN: 2243-7711

\section{Abstract}

Transition from introductory to advance STEM courses is a "leaky" pipeline; attrition is a major concern. Implementation of a peer-led team learning (PLTL) - a learner-centered intervention - aimed to maximize interaction in the classroom was observed. Findings, however, were varied. This scoping review using Arksey and O'Malley's (2005) five-stage framework was conducted to show the apparent effects of implementing PLTL workshop to performance of learners and its influence to peer leaders. The results indicate better performance of learners who participated in the PLTL workshops and positive influence to peer leaders. The results further emphasized that PLTL is generally useful to both participants and leaders. The implications and recommendations for future research are also discussed.

Keywords: peer support; pedagogy; intervention; better performance 


\section{A scoping review of the peer-led team learning to learner-participants and peer leaders in STEM courses}

\section{Introduction}

Higher education has seen the potential effectiveness of a learner-centered instruction compared to the teacher-centered training. Research suggests that learner-centered pedagogies promote a more independent learning community (Irvine, Code, \& Richards, 2013; Tutty \& Klein, 2008; Smith, Wilson, Banks, Zhu, and Varma-Nelson, 2014). In addition, recent, extensive meta-analysis of over a decade of education research has revealed an overwhelming consensus that active learning methods are superior to traditional, passive lecture, in terms of student achievement in post-secondary Science, Technology, Engineering, and Mathematics (STEM) courses (Snyder, Sloane, Dunk, \& Wiles, 2016). In active processes where students engage into the process, create, and construct their own knowledge support development of higher level reasoning, conceptual understanding (Chan \& Bauer, 2015), better participation and performance (Bellen \& Jomoc, 2017) and improve attitude (Campit \& Garin, 2017). Small group learning is considered a best practice in undergraduate education.

Successful science learning depends on the interaction of individuals with different skills, ideas, and backgrounds, often working in teams. The social process of developing and negotiating understanding through debate and discussion with peers in the classroom (Gosser, Kampmeier, \& Varma-Nelson, 2010) and an emerging online platform (Marja, Satu, \& Kaarina, 2013) is central to both science and learning. With the view that active learning promotes better performance, interventions are focused on the maximum participation of the learners in the process, e.g., the peer-led team learning (PLTL). Theoretical frameworks of PLTL are anchored on constructivism and social learning theory (Wilson \& Varma-Nelson, 2015; Gafney \& Varma-Nelson, 2007; Wamser, 2006). In social constructivism, knowledge exists in a social context and is initially shared with others instead of being represented solely in the mind of an individual (Corpuz, Lucas, Borabo, \& Lucido, 2015). Wilson and Varma-Nelson (2015) asserts that in the discussion of different processes of solving problems and debate about interpretation of data are socio-collaborative tasks in which participants construct meaning during their group interactions as they practice constructing, negotiating, evaluating, and defending their understanding. In the social learning theory, the peer leaders served as role models to their groups, the learners that are part of the group might be influenced on the behavior and achievements of the leader which could motivate them to follow or even surpass them, and that means a better learning.

In PLTL workshop, students work in small groups of six to eight students, led by an undergraduate peer leader who has successfully completed the same course in which their peer team students are currently enrolled. After being trained in group leadership methods, relevant learning theory, and the conceptual content of the course, peer leaders, work collaboratively with an education specialist and the course instructor to facilitate small group problem-solving. Leaders are trained on pedagogical techniques to facilitate group-work without relying on a transmission-oriented method of knowledge transfer and help mentor students to actively construct their own understanding of concepts. Literature revealed that PLTL contribute to an improved student learning experience. These key aspects include; student-centered activities, participation of underrepresented minorities, as well as gender and development. In addition, the researchers wished to explore the outcomes of PLTL to the leaders using scoping review methodology.

O'Flaherty and Phillips (2015) succinctly describe the advantages of scoping reviews (or scoping studies) in education and allied fields. They opined that scoping reviews differ from systematic reviews in that the "latter are utilized to answer precise questions, with defined methodologies to assess article quality, while the former are relevant in fields containing a paucity of rigorous evidence, therefore incorporating literature that encompasses a broad range of study designs". Moreover, scoping review is an effective means of "highlighting the relevant literature to the researcher, with the aim of rapid mapping of key concepts underpinning a research

2 Consortia Academia Publishing (A partner of Network of Professional Researchers and Educators) 
A scoping review of the peer-led team learning to learner-participants and peer leaders in STEM courses area" and a robust method of "identifying primary and secondary sources of literature".

Potential benefits of PLTL is enormous in STEM education, however, summary is limited. This scoping review considers research findings and draws conclusions from the existing literature regarding the state of research activity on peer-led team learning.

\section{Methodology}

This scoping review followed Arksey and O'Malley's (2005) five-stage framework adopts a rigorous process of transparency, enabling replication of the search strategy and increasing the reliability of the study findings. The stages of the framework include; (1) identifying the initial research questions, (2) identifying relevant studies, (3) study selection, (4) charting the data, and (5) collating, summarizing and reporting the results were utilized in this review of the PLTL literature.

\subsection{Identifying the initial research questions}

The focus of this review was the exploration of key aspects of the PLTL that influence the performance of the learners participating on the said program. To ensure that a substantial range of literature was captured relating to the topic of interest, the following initial research questions were formulated to guide the search:

What settings are mostly seen in implementing PLTL program/workshop?

$>$ How does PLTL participation affect the academic performance of learner-participants?

$>\quad$ Does gender and ethnicity of the learner-participants affect PLTL success?

$>\quad$ How does PLTL influence the learning, personal growth, and academic and career decisions of peer leaders?

\subsection{Identifying relevant studies}

Arksey and O'Malley (2005) suggest that a wide definition of key words for search terms should be adopted to glean a 'broad coverage' of available literature. Key concepts and search terms were developed to capture literature that related to PLTL. A research instructor advised on the possible journals containing valid information on research topics.

\section{Table 1}

Key search terms

\begin{tabular}{l}
\hline \multicolumn{1}{c}{ Search terms } \\
\hline Peer-led team learning \\
'peer-led team learning published on 2006' \\
'effect of peer-led team learning to peer leaders' \\
\hline
\end{tabular}

The input was useful in the refinement of key search terms and identifying databases most likely to produce the results sought. Techniques for searching included the use of search tools such as educational subject headings and Boolean operators to narrow, widen and combine literature searches. The linked descriptive key search terms that were developed to guide the search are outlined in Table 1. In being as comprehensive as possible in the identification of primary evidence, and cognizant of the practicalities of time and monetary constraints (Kenny, Hyett, Sawtell, Dickson-Swift, Farmer, \& O'Meara, 2013), inclusion and exclusion criteria were developed. Research prior to this time was considered to have been reflected and of the same findings with the included researches. The time period 2006 to 2018 was considered appropriate. A full list of inclusion and exclusion criteria is outlined in Table 2. A hand search of the reference lists of identified articles was undertaken and Google Scholar was utilized to identify any other primary sources within grey literature. Also, the databases 
Guden, J. M., \& Bellen, J. A.

Psych Info, MEDLINE, and ERIC were searched. The review of literature was completed over three months ending in March 2019.

Table 2

Inclusion and exclusion criteria

\begin{tabular}{|c|c|c|}
\hline Criterion & Inclusion & Exclusion \\
\hline Time period & 2006 to 2018 & Studies outside these dates \\
\hline Language & English & Non-English studies \\
\hline $\begin{array}{l}\text { Type of } \\
\text { article/publication }\end{array}$ & $\begin{array}{l}\text { Original research and published in a } \\
\text { journal }\end{array}$ & $\begin{array}{l}\text { Articles that were not published and } \\
\text { not original }\end{array}$ \\
\hline Study focus & $\begin{array}{l}\text { Undergraduate students in higher } \\
\text { education }\end{array}$ & All other students \\
\hline Literature focus & $\begin{array}{l}\text { Articles that talks about the extent of } \\
\text { PLTL in the learning process }\end{array}$ & $\begin{array}{l}\text { Articles that do not talk directly about } \\
\text { PLTL } \\
\text { Articles that talks about PLTL } \\
\text { effectiveness along with other } \\
\text { interventions }\end{array}$ \\
\hline Population and sample & $\begin{array}{l}\text { Undergraduate STEM students enrolled } \\
\text { in a recognized program of study. }\end{array}$ & $\begin{array}{l}\text { All other students not enrolled in } \\
\text { undergraduate studies. }\end{array}$ \\
\hline
\end{tabular}

\subsection{Study selection}

Using the key search descriptors, 12,700 articles were suggested in Google Scholar, 50 articles in Psych Info, 17 articles in MEDLINE, and 70 articles from ERIC. A review of the abstracts revealed large numbers of articles that were irrelevant, particularly those related to primary and secondary education settings utilizing PLTL. Most of the articles were identified using Google Scholar. Titles and abstracts identified in the searching process were evaluated against the eligibility criteria by both reviewers, separately on a random sample of $10 \%$ as quality check. The resulting articles where compared and disagreements were discussed together. The task was repeated until 95\% of concordance among reviewers was obtained (Campana \& Lapointe, 2012; Murray, Daines, Archibald, Hawkes, Grant, \& Mutrie, 2016). Twenty four studies were identified as being relevant to the research topic. Full text versions of the articles were obtained, with each article being independently reviewed and confirmed as appropriate. This process provided an opportunity to identify any further additional relevant literature from a review of the reference lists of each article. The process of article selection followed the Preferred Reporting of Items for Systematic Reviews and Meta-Analyses (PRISMA) Statement (Moher, Liberate, Tetzlaff, Altman, \& The PRISMA Group, 2009). Figure 2 below illustrates the process of article selection. During the process of study selection, several studies were excluded. Examples include studies that detailed extensive reports on the use of PLTL in primary education and secondary education, where the focus of the scoping review is the higher education sector (Flumerfelt \& Green, 2013; Fulton, 2012), conference proceedings and other non-refereed publications (Allen, 2013; Mehta, Hull, Young \& Stoller, 2013; Pluta, Richards, \& Mutnick, 2013).

\subsection{Data charting and collation}

The fourth stage of Arksey and O'Malley's (2005) scoping review framework was charting of selected articles. Summaries were developed of each article related to the author, year, location of study, study design, study methods and sample size and a brief comment on the limitations and recommendations of the individual selected study. Detail of included studies is provided in Table 3.

4 Consortia Academia Publishing (A partner of Network of Professional Researchers and Educators) 

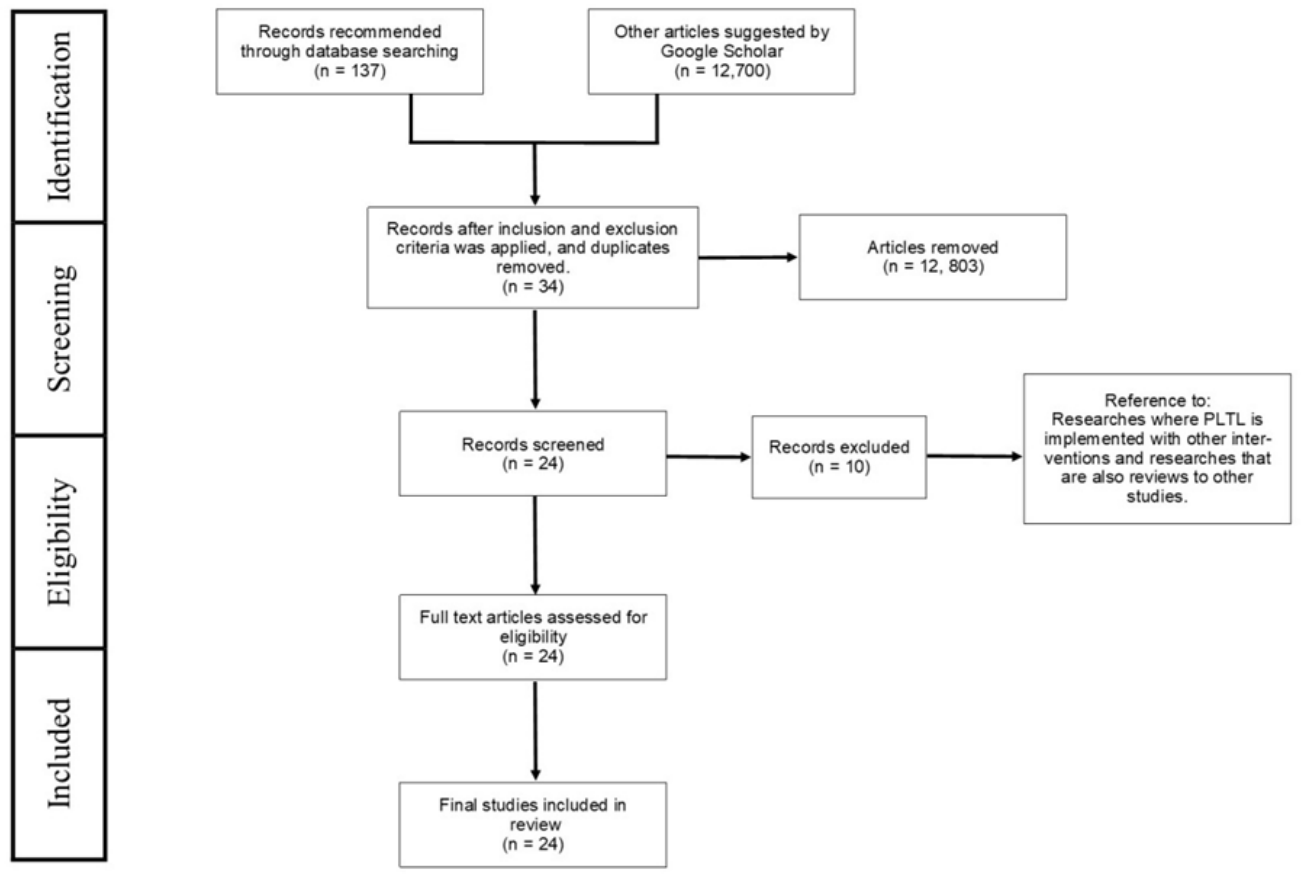

Figure 1. PRISMA flowchart of article selection

Table 3

Included studies

\begin{tabular}{|c|c|c|c|}
\hline $\begin{array}{l}\text { (Study number) } \\
\text { Author details }\end{array}$ & Intervention setting & $\begin{array}{c}\text { Study design / } \\
\text { Participants sample }\end{array}$ & Outcomes \\
\hline $\begin{array}{l}\text { (1) Hockings, } \\
\text { DeAngelis, and Frey } \\
\text { (2008) }\end{array}$ & $\begin{array}{l}\text { Voluntary recruitment of } \\
\text { PLTL participants. } \\
\text { However, when the } \\
\text { participant enrolled, a } \\
\text { mandatory attendance is } \\
\text { observed. } \\
\text { PLTL groups of } \\
\text { approximately eight } \\
\text { students meet weekly } \\
\text { either on Saturday or on } \\
\text { Sunday for two hours each. }\end{array}$ & $\begin{array}{l}\mathrm{N}=1125 \\
\text { Quantitative comparison of } \\
\text { the performance and } \\
\text { attitude of PLTL versus } \\
\text { non-PLTL students }\end{array}$ & $\begin{array}{l}\text { PLTL students show a better performance than non-PLTL } \\
\text { students. PLTL students also show positive attitudes to } \\
\text { the program. }\end{array}$ \\
\hline $\begin{array}{l}\text { (2) Frey, Fink, Cahill, } \\
\text { McDaniel, and } \\
\text { Solomon (2018) }\end{array}$ & $\begin{array}{l}\text { Students self-select into } \\
\text { General Chemistry PLTL } \\
\text { through an online } \\
\text { application, which } \\
\text { guarantees assignment to a } \\
\text { PLTL group. Once } \\
\text { students enroll in PLTL, } \\
\text { participation becomes } \\
\text { mandatory. Participants } \\
\text { together with the peer } \\
\text { leader met at Saturdays or } \\
\text { Sundays for } 2 \text { hours mostly } \\
\text { to solve problems. }\end{array}$ & $\begin{array}{l}\mathrm{N}=1254 \\
\text { Quantitative investigation } \\
\text { on the influence of PLTL } \\
\text { to students' performance in } \\
\text { general chemistry I course. }\end{array}$ & $\begin{array}{l}\text { PLTL is generally effective. Five years of performance } \\
\text { data from General Chemistry I revealed no interaction } \\
\text { between student demographics (race and sex) and the } \\
\text { PLTL effect: PLTL participation had a uniformly positive } \\
\text { effect across all identity groups. }\end{array}$ \\
\hline $\begin{array}{l}\text { (3) Quitadamo, } \\
\text { Brahler, and Crouch } \\
\text { (2009) }\end{array}$ & $\begin{array}{l}\text { Four to eight students met } \\
\text { weekly with their peer } \\
\text { leader to address the } \\
\text { problem set, which was } \\
\text { provided at the beginning } \\
\text { of each session. }\end{array}$ & $\begin{array}{l}\mathrm{N}=552 \\
\text { Quantitative research on } \\
\text { the effect of PLTL to } \\
\text { students' critical thinking } \\
\text { taking science and math } \\
\text { courses. It also establishes } \\
\text { a relationship of the } \\
\text { effectiveness of PLTL to } \\
\text { demographics. }\end{array}$ & $\begin{array}{l}\text { PLTL improves students critical thinking skills in science } \\
\text { but not in mathematics. Gender, ethnicity, class standing, } \\
\text { and academic term did not significantly affect critical } \\
\text { thinking gains. }\end{array}$ \\
\hline
\end{tabular}


Guden, J. M., \& Bellen, J. A.

Table 3 ... continued

(Study number)

Author details

(4) Wamser (2006)

(5) Gafney and

Varma-Nelson (2007)

Preszler (2009)

(7) Mitchell, Ippolito, and Lewis (2012)

(8) Snyder, Sloane

Dunk, and Wiles

(2016)

(10) Streitwieser and Light (2010)

(11) Chan and Bauer (2015)
Study design /

Participants sample

Participants showed success, persistence, and

performance. Student attitudes towards the workshops were very positive and suggest some of the underlying causes of the gains.

workshop) to assis

students in learning

problem solving by

working in small teams,

under the guidance of a

rained peer leader.

Peer leaders facilitate the

$\mathrm{N}=1273$

Quantitative presentation

of data on the effect of

PLTL workshop to

students' success,

persistence, and

performance based from

the five-year data.

Quantitative and

classes. Most of them

served more than one year

as peer leader and attended

leader training program.

Students are required to

attend two 50-min lectures

each week and one 65-min

workshop led by peer

facilitators doing

learning-skill sessions to

case studies.

pre-workshop semesters to

Classes were

offered that meet for three,

50 min sessions per week,

where two sessions were

primarily lecture and the

third was designated for

the PLTL implementation.

Science Workshop

Program, a series of

small-group,

peer-facilitated workshops

open to first- and second

year students in biology,

chemistry, physics,

engineering, mathematics

and Organic Chemistry.

PLTL is a structured form

of group learning where a

small group of six to eight

students meets weekly to

discuss and solve problems

related to topics covered in

lectures. These groups are

led by a trained peer who

earned at least a B in the

same course in the

previous year.
$\mathrm{N}=119$

qualitative investigation on

the longer term impacts of

PLTL to the leaders.

$\mathrm{N}=$ different from every

semester from 2003 to

2006.

Quantitative comparison

on the students'

performance in

student performance after

replacing one lecture

session with PLTL

workshop.

$\mathrm{N}=$ ranges from 45 to 70

students depending on the

enrollment population per

semester from 2010 to

2011.

Quantitative presentation

of data on the effect of

implementing PLTL in

General Chemistry classes.

$\mathrm{N}=479$

Quantitative study on the

effect of PLTL to the

academic achievement of

underrepresented

minorities in STEM fields

and their retention to the

course

$\mathrm{N}=$ varies from 50 to 75 .

Workshop leaders reap significant, ongoing benefits from their roles such as gaining thorough knowledge on a particular discipline, became a better problem solver, improved confidence and patience in communicating with other people, and an increased rate and appreciation to teaching.

PLTL workshops improved understanding and interest of biology. A very strong majority of students strongly agreed or agreed that attending two lectures and one workshop is more valuable than attending three lectures each week. Both males and females benefited from the workshops, females' grades and retention improved significantly more than that of males.

It is argued that there is evidence of PLTL facilitation of students' knowledge acquisition, as more students were able to achieve passing scores with the reform pedagogy than with traditional instruction.

Higher retention for students who enrolled in PLTL, with those who did not attend PLTL sessions being significantly more likely to withdraw from the course. Underrepresented minorities in PLTL have higher student achievement.

The results indicate a notable $15 \%$ improvement in student retention, in terms of passing general chemistry, when using PLTL versus a traditional lecture. It appears that the gains in passing the course were uniform across student groups, with the strong potential for improving the performance of students from underrepresented minority groups.

Study shows that while in the eyes of the program the

$\mathrm{N}=19$

Qualitative research on the conceptions and approaches of PLTL leaders to teaching in the span of the two-year implementation of the program.

$\mathrm{N}=600$

Quantitative investigation on the effect of PLTL participation on students exam achievement and affective characteristics in general chemistry classes. facilitators may serve primarily as a meansfor improving student performance, the facilitators are not a homogenous group: they have highly unique undergraduate experiences which they perceive in dramatically different ways.

PLTL helps students learn if they take advantage of it. No differences were found in achievement, attitude, or self-concept for students who participated in PLTL vs. those who participated in documented alternative study activities. 
Table 3 ... continued

(Study number)

Author details

(12) Smith, Wilson,

Banks, Zhu, and

Varma-Nelson (2014)

13) Biggers, Yilmaz and Sweat (2009)

(14) Becvar, Dreyfuss, Flores, and Dickson (2008)

(15) Keenan (2014)

(16) Carlson, Celotta Curran, Marcus, and Loe (2016)

(17) Platt, Roth, and Kampmeier (2008)

(18) Johnson, Robbins, and Loui (2015)

\section{Intervention setting}

PLTL workshop sections contained between 8 and

12 students and the cPLTL sessions were somewhat smaller having between 6 and 8 students per workshop, due to technology constraints.

Workshop students participated in collaborative activities which took place in a variety of small group configurations throughou the semester including occasional dyads with a pair programming approach.

Plus Two PLTL: The three hours lecture per week was changed to two and the one-hour session was replaced with the PLTL workshop.

Students were formed into smaller groups with a peer leader mostly composed of second year undergraduate students

STEM Learning

Community (LC) Program modeled after PLTL, was formed at private medium-sized, liberal-arts university in the midwest of the United States to serve students enrolled in introductory biology, chemistry, mathematics and statistics units.

Established a partnership of faculty, education specialists, and student peers working together to help all the students in the course construct conceptual understanding and develop problem-solving skills. Students join PLTL sessions optionally. Teams met for ninety-minute workshops on Sunday afternoons or evenings. During the PLTL sessions, each team cooperatively solved difficult problems that were selected by the course instructors. After which the peer leaders were asked to keep reflective journals, writing for 15 to 30 minutes after each session.
Study design / Participants sample

Outcomes

$\begin{array}{ll}\mathrm{N}=395 & \text { Comparable educational outcomes with respect to mean } \\ \text { Quantitative and } & \text { course grade and ACS General Chemistry exam scores } \\ \text { qualitative comparison on } & \text { between PLTL and cPLTL students. }\end{array}$

qualitative comparison on the effect of PLTL and Cyberspace PLTL to students outcomes on chemistry classes.

$\mathrm{N}=589$

Quantitative description of the effect of PLTL participation on students' success and retention on computer science class.

Descriptive report on the effect of PLTL on students retention rate in general chemistry subjects from 1997-2004

Descriptive research on the effect of peer-led workshop on the student leaders, participants, and institutions.

Mixed methods studying the effectiveness of PLTL program on learning STEM education specially biology, chemistry, mathematics, and applied statistics.

Descriptive research on the impact of PLTL workshop to students performance in organic chemistry and biochemistry.

Qualitative description of the experiences of peer leaders in an introductory engineering course.
Course outcomes in terms of student success were significantly and positively impacted by introducing a collaborative PLTL approach to the introductory computer science class.

Students in PLTL showed

higher retention rates for each of the four subsequent semesters than students who took general chemistry prior to the implementation of 'Plus Two' PLTL Chemistry Workshop.

Peer leaders gained leadership and communication skills. Participants have improved academic confidence. The institutions see it as a good tool in improving student experience, enhancing engagement, belongingness, retention, and success.

Results indicate program participants reliably outperform their matched pairs in courses that emphasize quantitative reasoning.

Research show positive results on the impact of the workshops to students performance. The participants argued that they value the workshop.

Peer leaders had changed throughout the semester. The leaders were apprehensive and worried about their own limitations. Throughout the semester, the leaders faced many challenges and took actions to improve cooperation within their teams. These leaders reflected on their teaching methods, recognized their own limitations, and began to appreciate intellectual diversity. By the end of the semester, they expressed increased self-confidence and interest in teaching or mentoring in the future. 
Guden, J. M., \& Bellen, J. A.

Table 3 ... continued

\begin{tabular}{|c|c|c|c|}
\hline $\begin{array}{l}\text { (Study number) } \\
\text { Author details }\end{array}$ & Intervention setting & $\begin{array}{c}\text { Study design / } \\
\text { Participants sample }\end{array}$ & Outcomes \\
\hline $\begin{array}{l}\text { (19) Schray, Russo, } \\
\text { Egulf, Lademan, and } \\
\text { Gelormo (2009) }\end{array}$ & $\begin{array}{l}\text { Groups of eight (or less) } \\
\text { students were allowed to } \\
\text { self-form, led by standard } \\
\text { peer leaders and in-class } \\
\text { peer leaders for one to one } \\
\text { and a half hours. }\end{array}$ & $\begin{array}{l}\text { Quantitative comparison } \\
\text { on the effectiveness of } \\
\text { learning outcomes made by } \\
\text { standard peer leaders } \\
\text { versus in-class peer } \\
\text { leaders. }\end{array}$ & $\begin{array}{l}\text { In-class peer leaders are as effective as standard peer } \\
\text { leaders, though they have slightly different modes of } \\
\text { operation. Academic performance and student satisfaction } \\
\text { are virtually identical. }\end{array}$ \\
\hline $\begin{array}{l}\text { (20) Sawyer, Frey, and } \\
\text { Brown (2013) }\end{array}$ & $\begin{array}{l}\text { PLTL workshop was } \\
\text { conducted led by peer } \\
\text { leaders with different } \\
\text { styles, facilitative, and } \\
\text { facilitative and instructive. }\end{array}$ & $\begin{array}{l}\mathrm{N}=2 \text { peer leader each with } \\
\text { different PLTL workshop } \\
\text { group facilitated. } \\
\text { Qualitative comparison on } \\
\text { the effectiveness of using } \\
\text { facilitative style, and } \\
\text { facilitative and instructive } \\
\text { styles in chemistry classes. }\end{array}$ & $\begin{array}{l}\text { This study has shown that not all peer group experiences } \\
\text { are equally effective at promoting student knowledge } \\
\text { building. A frequent intellectual conversation increased } \\
\text { learning. }\end{array}$ \\
\hline $\begin{array}{l}\text { (21) Johnson and Loui } \\
\text { (2009) }\end{array}$ & $\begin{array}{l}\text { Students work on difficult } \\
\text { problems from previous } \\
\text { semesters' exams under the } \\
\text { supervision of a team } \\
\text { leader. }\end{array}$ & $\begin{array}{l}\mathrm{N}=14 \\
\text { Qualitative study on the } \\
\text { peer leaders to } \\
\text { self-confidence, view on } \\
\text { diversity, and interest in } \\
\text { teaching in electronic } \\
\text { classes. }\end{array}$ & $\begin{array}{l}\text { The leaders of the learning teams benefited from } \\
\text { overcoming challenges, recognizing their limitations, and } \\
\text { appreciating intellectual diversity. They expressed } \\
\text { increased self-confidence and interest in future teaching } \\
\text { and mentoring. }\end{array}$ \\
\hline $\begin{array}{l}\text { (22) Mottley and Roth } \\
\text { (2013) }\end{array}$ & $\begin{array}{l}\text { Peer leaders meet weekly } \\
\text { with small groups of } \\
\text { students to guide them } \\
\text { through sets of exercises } \\
\text { designed by the } \\
\text { instructor(s) of the course. }\end{array}$ & $\begin{array}{l}\mathrm{N}=344 \text { (from 2005-2009) } \\
\text { Mixed research on the } \\
\text { effect on including PLTL } \\
\text { workshop to students' } \\
\text { performance in electronic } \\
\text { classes. }\end{array}$ & $\begin{array}{l}\text { There is a modest increase in students' performance, and } \\
\text { expression of satisfaction of participants, leaders, and } \\
\text { instructors. }\end{array}$ \\
\hline $\begin{array}{l}\text { (23) Stewart-Gardiner } \\
\text { (2010) }\end{array}$ & $\begin{array}{l}\text { Weekly workshops were } \\
\text { conducted by solving } \\
\text { problems led by peer } \\
\text { leaders. }\end{array}$ & $\begin{array}{l}\text { Quantitative comparison of } \\
\text { students' perception on } \\
\text { PLTL workshops in } \\
\text { computer science classes. }\end{array}$ & $\begin{array}{l}\text { PLTL workshops in computer science can improve } \\
\text { retention and a sense of community among STEM } \\
\text { students. }\end{array}$ \\
\hline $\begin{array}{l}\text { (24) Muller, Shacham, } \\
\text { and Hersovitz (2017) }\end{array}$ & $\begin{array}{l}\text { The PLTL program } \\
\text { accompanies STEM } \\
\text { introductory courses with a } \\
\text { high rate of failures, and } \\
\text { incorporates workshops of } \\
\text { small groups of students } \\
\text { for developing } \\
\text { active-learning and } \\
\text { problem-solving skills }\end{array}$ & $\begin{array}{l}\mathrm{N}=1380 \\
\text { Qualitative and } \\
\text { quantitative description on } \\
\text { the effect of PLTL } \\
\text { workshop in students' } \\
\text { achievement and peer } \\
\text { leaders' gain in } \\
\text { engineering subjects. }\end{array}$ & $\begin{array}{l}\text { Workshops improved the participating students' } \\
\text { achievements; they accomplished better grades and lower } \\
\text { course dropout rates compared to non-participants in most } \\
\text { of the courses. The peer leaders believed that the program } \\
\text { contributes to their personal growth and believed they } \\
\text { acquired valuable skills for their professional and personal } \\
\text { lives, i.e., academic learning, mentoring skills, and } \\
\text { emotional growth. }\end{array}$ \\
\hline
\end{tabular}

\subsection{Summarizing and reporting findings}

The fifth and final stage of Arksey and O'Malley's (2005) scoping review framework summarizes and reports findings.

\section{Results and discussion}

This scoping review yielded 24 articles from two countries. Of these, 23 studies were conducted in the United States, and one in the United Kingdom. In this section we present articles which were the focus of our initial research questions. They included articles with discussion on the setting created while implementing the PLTL workshop, the effect of PLTL to learner-participants and leaders, and advantages in engaging to PLTL workshop.

\subsection{What settings are mostly seen in implementing PLTL program/workshop?}

Some researchers have cited that PLTL workshop is optional but would require mandatory attendance when the learner opted to join. It is designed into small groups ranging from 6-8 students with an assigned peer leader (Biggers et al., 2009; Chan \& Bauer, 2015; Hockings, DeAngelis, \& Frey, 2008; Johnson, Robbins, \& Loui,

8 Consortia Academia Publishing (A partner of Network of Professional Researchers and Educators) 
2015; Quitadamo, Brahler, \& Crouch, 2009; Schray, Russo, Egolf, Lademan, \& Gelormo, 2009; Smith et al., 2014; Snyder et al., 2016; Wamser, 2006) and meet in weekly basis. Peer leaders are those students who previously took the same course as the participants are currently taking, gained an appreciably good performance, and are properly trained. Some literatures cited that the workshop were conducted on Saturdays or Sundays (Frey, Fink, Cahill, McDaniel, \& Solomon, 2018; Hockings et al., 2008; Johnson et al., 2015) while some replaced one hour of the original schedule of a particular subject with the workshop (Becvar, Dreyfuss, Flores, \& Dickson, 2008; Lewis, 2011; Preszler, 2009; Schray et al., 2009). Further, most of the subjects where PLTL was implemented were STEM subjects such as chemistry, biology, physics, mathematics, and engineering course. With these, the workshop focused on problem-solving method related to the lessons in the regular classes of the learners.

Even though the PLTL recruitment was not mandatory; there were still an appreciable number of participants who joined the workshop. This suggests that participants might have already seen positive impacts of the workshop to their performance that pushed them to join. Consequently, it later became congruent to their act after the workshops. Another observation was that the participants were grouped into smaller number. This setting must have been made to maximize active learning among learners and facilitators. It is because as the number of learners decrease in a particular setting, the more frequent the teacher can accommodate and entertain their concerns. Moreover, with regards to the kind of peer leaders, there is an arguably good choice of it since these leaders are from the group of learners but of higher year level. Given this feature, there is a lesser tendency of generational gap which led the learners to be more cooperative, communicative and confident with them. Talking about the time consumed, there is reasonable and no significant loss of time for the participants' other activities since it only required an hour in a week. The most common approach observed in the workshop was problem-solving. This emphasized that STEM courses became challenging for its mathematical nature but can also be better addressed using the nature itself and a constant practice in solving problems.

\subsection{How does PLTL participation affect the academic performance of learner-participants?}

PLTL participants significantly showed better performance, enhanced critical thinking skills, showed positive attitude towards learning, exemplified retention on their course of choice, demonstrated persistence on the subject matter, portrayed success on the subject they are participating, and revealed a better understanding on their subjects than those students who have not participated in the workshop (Biggers et al., 2009; Becvar et al., 2008; Carlson, Celotta, Curran, Marcus, \& Loe, 2016; Chan and Bauer, 2015; Frey et al., 2018; Hockings et al., 2008; Keenan, 2014; Mitchell, Ippolito, \& Lewis, 2012; Mottley \& Roth, 2013; Muller, Shacham, \& Hersovitz, 2017; Platt, Roth, \& Kampmeier, 2008; Preszler, 2009; Quitadamo et al., 2009; Schray et al., 2009; Smith et al., 2014; Snyder et al., 2016; Stewart-Gardiner, 2010; Streitwieser \& Light, 2010; Wamser, 2006). Furthermore, participants expressed satisfaction on the program, emphasized that they have built a sense of community among their co-participants, (Stewart-Gardiner, 2010) and reported to have valued the program. However, Chan and Bauer (2015) suggested that performance could only be enhanced if participants take it seriously. Also, performance is still a function of how the peer leaders hold the workshops (Sawyer, Frey, \& Brown, 2013).

Participants have significant gains. Looking at these closely, the improvements can be classified base on the two domains of learning - the cognitive and affective faculties. The increased rate of performance to the subject, higher grades, enhanced critical thinking skills, and success and the deeper understanding on the subjects are manifestations of the improvement of the cognitive faculty. Meanwhile, the learners' retention to their course, the persistence on the subject, and the satisfaction and the report of valuing the experience upholds the development of their affective faculty.

\subsection{Does gender and ethnicity of the learner-participants affect PLTL success?}

Generally, gender and ethnicity did not affect students' rate of performance when they participated in PLTL workshop. Literature shows that the participants have gained better performance compared to those who did not 
participate on the workshop (Frey et al., 2018; Lewis, 2011; Quitadamo et al., 2009; Snyder et al., 2016). For instance, in the studies revealed that PLTL participation had a uniformly positive effect across all identity groups (Frey et al., 2018; Lewis, 2011). However, Preszler (2009), shows that although the grades of both males and females benefited from the workshops, females' grades and retention improved significantly more than that of males.

The findings suggest that irrespective of the gender and race, the workshop is applicable and effective. However, when compared within the PLTL participants group, it was found out the females outperformed males. A collaborative nature of PLTL supported increased female performance and retention since males are more responsive to competitions than collaborations (Quitadamo et al., 2009). Additionally, the development of an individualized dialogue of the females with the instructors or facilitators provides them with personal encouragement thereby enhancing their performance which is treated to be of less important to males (Preszler, 2009).

\subsection{How PLTL influence the learning, personal growth, and academic and career decisions of peer leaders?}

Articles in this scoping review revealed that peer leaders have gained positive and transformative experiences (Gafney \& Varma-Nelson, 2007; Johnson et al., 2015; Johnson \& Loui, 2009; Keenan, 2014; Muller et al., 2017; Streitwieser \& Light, 2010). Leaders suggested that they have an increased knowledge and understanding on the subject that they are engaging, identified approaches relevant to a particular topic, able to appreciate intellectual diversity, and enhanced their leadership skills and patience in working with others. They also have gained confidence in communicating with others as well as a better perspective and interest in teaching practice. Some leaders identified their experience as the most productive college experience. Further, in the process of facilitating the workshop, they have acknowledged a ladder of improvement on their teaching skills in the scenario of being apprehensive, worried, and frustrated to the difficulty of teaching before recognizing their own teaching methods and gaining self-confidence (Johnson et al., 2015; Muller et al., 2017; Streitwieser \& Light, 2010). Some of the leaders are then continuing their education and the education of others. Results show that teaching or facilitating not only teaches the facilitators the process but also the contents. The leaders also have developed the sense of responsibility to their mentees as reflected on their responses of being able to see intellectual differences and able to build patience. In support, Johnson et al. (2015) speculated that the leaders were able to build their self-identity.

\section{Conclusion}

Peer-led team learning has impacted a significant and positive influence and effect on the performance of the learner-participants and leaders. Evidence showed increase in the grades, higher retention rates, and success in the courses of the learner-participants. Likewise, the peer leaders developed essential skills in learning, communication, and life and career skills. While benefits were apparent, there were limitations seen which other ongoing researches should consider. The optional nature of the PLTL program means that motivational differences between the groups could underlie the PLTL effect, rather than the experience of PLTL per se (Frey et al., 2018). Chan and Bauer (2015), have demonstrated that PLTL effects may stem partially from more motivated students opting into such programs. In addition, Sawyer et al. (2013), recommended that instructors or facilitators should design PLTL problems to begin with guiding questions that allow for students to discuss key concepts and experiments in addition to equations and variables. In this way, the students are able to unveil prior knowledge and review the phenomena discussed in lectures, recitations, and other problems which would later provide a more accurate research results. Moreover, with regards to the participants, students' prior involvement in other workshops and the diversity of students' experiences should be noted since it could contribute to the variability in the performance (Carlson et al., 2016). Lastly, with regards to the gathering of data on peer leaders' views, it should be considered that anonymity is minimized since it would increase the inability to distinguish reliably between experienced and new leaders (Johnson \& Loui, 2009; Johnson et al., 2015). Introducing alternative assessment is one way that might confirm the leaders' responses.

10 Consortia Academia Publishing (A partner of Network of Professional Researchers and Educators) 


\section{References}

Allen, P. (2013). Preparing nurses for tomorrow's healthcare system. American Nurse Today, 8(5), 42-56.

Arksey, H., \& O'Malley, L. (2005). Scoping studies: towards a methodological framework. International Journal of Social Research Methodology, 8(1), 19-32. https://doi.org/10.1080/1364557032000119616

Becvar, J. E., Dreyfuss, A. E., Flores, B. C., \& Dickson, W. E. (2008). 'Plus two' peer-led team learning improves student success, retention, and timely graduation. 38th ASEE/IEEE Frontiers in Education Conference (pp. 15- 18). New York: IEEE. https://doi.org/10.1109/FIE.2008.4720327

Bellen, J. A., \& Jomoc, A. B. (2017). Supporting struggling grade 8 science students' motivation, participation and performance through peer-tutoring approach. Annals of Tropical Research, 39(1). 146-155. https://doi.org/10.32945/atr39110.2017

Biggers, M., Yilmaz, T., \& Sweat, M. (2009). Using collaborative, modified peer led team learning to improve student success and retention in into CS. In the Proceedings of the 40th SIGCSE Technical Symposium on Computer Science Education (pp. 9-13). Chattanooga: ACM SIGCSE Bulletin. https://doi.org/10.1145/1539024.1508872

Campana, A., \& Lapointe, L. (2012). The structural "root" causes of non-suicide terrorism: a systematic scoping review. Terrorism and Political Violence, 24(1), 79-104. https://doi.org/10.1080/09546553.2011.611547

Campit, J. B. \& Garin, R. M (2017). The effect of peer learning on students' attitude toward mathematics. Asia Pacific Journal of Education, Arts and Sciences, 4(4), 10-15.

Carlson, K., Celotta, D. T., Curran, E., Marcus, M., \& Loe, M. (2016). Assessing the impact of a multi-disciplinary peer-led-team learning program on undergraduate STEM education. Journal of University Teaching \& Learning Practice, 13(1). Retrieved from http://ro.uow.edu.au/jutlp/vol13/iss1/5

Chan, J. Y., \& Bauer, C. F. (2014). Effect of peer-led team learning (PLTL) on student achievement, attitude, and self-concept in college general chemistry in randomized and quasi experimental designs. Journal of Research in Science Teaching, 52(3), 319-346. https://doi.org/10.1002/tea.21197

Corpuz, B. B., Lucas, M. R., Borabo, H. L., \& Lucido, P. I. (2015). Child and adolescent development: Looking at learners at different life stages. Quezon City: Lorimar Publishing, Inc.

Flumerfelt, S., \& Green, G. (2013). Using lean in the flipped classroom for at risk students. Educational Technology \& Society, 16(1), 356-366.

Frey, R. F., Fink, A., Cahill, M. J., McDaniel, M. A., \& Solomon, A. E. (2018). Peer-led team learning in general chemistry interactions with identity, academic preparation, and a course-based intervention. Journal of Chemical Education, 95(12), 2103-2113. https://doi.org/10.1021/acs.jchemed.8b00375

Fulton, K. (2012). Upside down and inside out: Flip your classroom to improve student learning. Learning \& Leading with Technology, 22(8), 12-17.

Gafney, L., \& Varma-Nelson, P. (2007). Evaluating peer-led team learning: A study of long-term effects on former workshop peer leaders. Journal of Chemical Education, 84(3), 535-539. https://doi.org/10.1021/ed084p535

Gosser, D. K., Kampmeier, J. A., \& Varma-Nelson, P. (2010). Peer-led team learning: 2008 James Flack Norris award address. Journal of Chemical Education, 7(4), 374-380. https://doi.org/10.1021/ed800132w

Hockings, S., DeAngelis, K., \& Frey, R. (2008). Peer-led team learning in general chemistry: implementation and evaluation. Journal of Chemical Education, 85(7), 990-996. https://doi.org/10.1021/ed085p990

Irvine, V., Code, J., \& Richards, L. (2013). Realigning higher education for the 21st-century learner through multi-access learning. Journal of Online Learning and Teaching, 9(2), 172-186.

Johnson, E. C., \& Loui, A. M. (2009). Work in progress - How do students benefit as peer leaders on learning teams? 39th ASEE/IEEE Frontiers in Education Conference (pp. 1- 2). Retrieved from https://files.eric.ed.gov/fulltext/EJ1077832.pdf

Johnson, E. C., Robbins, B. A., \& Loui, M. (2015). What do students experience as peer leaders of learning teams? School of Engineering Education Faculty Publications. https://doi.org/10.1109/FIE.2009.5350637

Keenan, C. (2014). Mapping student-led peer learning in the UK. The Higher Education Academy. Retrieved 
from https://www.heacademy.ac.uk/system/files/resources/peer_led_learning_keenan_nov_14-final.pdf

Kenny, A., Hyett, N., Sawtell, J., Dickson-Swift, V., Farmer, J., \& O'Meara, P. (2013). Community participation in rural health: A scoping review. Health Services Research, 13(64), 1-8.

https://doi.org/10.1186/1472-6963-13-64

Lewis, S. E. (2011). Retention and reform: An evaluation of peer-led team learning. Journal of Chemical Education, 88(6), 703-707. https://doi.org/10.1021/ed100689m

Marja, V., Satu, U., \& Kaarina, M. (2013). College students' experiences of and coping with loneliness possibilities of peer support. International Journal of Research Studies in Education, 2(4), 13-28. https://doi.org/10.5861/ijrse.2013.510

Mehta, N., Hull, N., Young, J., \& Stoller, J. (2013). Just imagine: New paradigms for medical education. Academic Medicine, 88(10), 1418-1423. https://doi.org/10.5861/ijrse.2013.510

Mitchell, Y. D., Ippolito, J., \& Lewis, A. S. (2012). Evaluating peer-led team learning across the two semester general chemistry sequence. Chemistry Education Research and Practice, 13(1), 378-383. https://doi.org/10.1039/c2rp20028g

Moher, D., Liberate, A., Tetzlaff, J., Altman, D., \& The PRISMA Group (2009). Preferred reporting items for systematic reviews and meta-analyses: The PRISMA statement. Physical Therapy, 89(9), 873-880. https://doi.org/10.1136/bmj.b2535

Mottley, J. G., \& Roth, V. (2013). Peer-led team learning: adjunct to lectures in an electrical engineering course for non-majors. 2013 IEEE frontiers in education conference (pp. 1027-1032). Oklahoma City: IEEE. https://doi.org/10.1109/FIE.2013.6684982

Muller, O., Shacham, M., \& Herscovitz, O. (2017). Peer-led team learning in a college of engineering: First-year students' achievements and peer leaders' gains. Innovations in Education and Teaching International, 55(6), 660-671. https://doi.org/10.1080/14703297.2017.1285714

Murray, A., Daines, L., Archibald, D., Hawkes, R., Grant, L., \& Mutrie, N. (2016). The relationship and effects of golf on physical and mental health: a scoping review protocol. British Journal of Sports Medicine, 50(1) 647-650. https://doi.org/10.1136/bjsports-2015-095914

O'Flaherty, J., \& Phillips, C. (2015). The use of flipped classrooms in higher education: A scoping review. Internet and Higher Education, 25(1), 85-95. https://doi.org/10.1016/j.iheduc.2015.02.002

Platta, T., Roth, V., \& Kampmeier, J. A. (2008). Sustaining change in upper level courses: peer-led workshops in organic chemistry and biochemistry. Chemistry Education Research and Practice, 9, 144-148. https://doi.org/10.1039/b806230g

Pluta, W., Richards, B., \& Mutnick, A. (2013). PBL and beyond: Trends in collaborative learning. Teaching and Learning in Medicine, 25(S1), S9-S16. https://doi.org/10.1080/10401334.2013.842917

Preszler, R. W. (2009). Replacing lecture with peer-led workshops improves student learning. Life Sciences Education, 82, 182-192. https://doi.org/10.1187/cbe.09-01-0002

Quitadamo, I. J., Brahler, C. J., \& Crouch, G. J. (2009). Peer-led team learning: A prospective method for increasing critical thinking in undergraduate science courses. Physical Therapy Faculty Publications, 18(1), 28-39.

Sawyer, K., Frey, R., \& Brown, P. (2013). Knowledge building discourse in peer-led team learning (PLTL) groups in first-year general chemistry. In D. S. Al, Productive multivocality in the analysis of group interactions (pp. 191-204). New York: Springer. https://doi.org/10.1007/978-1-4614-8960-3_10

Schray, K., Russo, M. J., Egolf, R., Lademan, W., \& Gelormo, A. D. (2009). Are in-class peer leaders effective in the peer-led team-learning approach? Journal of College Science Teaching, 38(4), 62-68.

Smith, J., Wilson, S. B., Banks, J., Zhu, L., \& Varma-Nelson, P. (2014). Replicating peer-led team learning in cyberspace: research, opportunities, and challenges. Journal of Research in Science Teaching, 51(6), 714-740. https://doi.org/10.1002/tea.21163

Snyder, J. J., Sloane, J. D., Dunk, R. D., \& Wiles, J. R. (2016). Peer-led team learning helps minority students succeed. PLOS Biology, 14(3). https://doi.org/10.1371/journal.pbio.1002398

Stewart-Gardiner, C. (2010). Using peer led team learning to assist in retention in computer science classes. Consortium for Computing Sciences in Colleges, 25(3), 164-171.

12 Consortia Academia Publishing (A partner of Network of Professional Researchers and Educators) 
A scoping review of the peer-led team learning to learner-participants and peer leaders in STEM courses

Streitwieser, B., \& Light, G. (2010). When undergraduates teach undergraduates: conceptions of and approaches to teaching in a peer led team learning intervention in the stem disciplines: results of a two year study. International Journal of Teaching and Learning in Higher Education, 22(3), 346-356.

Tutty, J., \& Klein, J. (2008). Computer-mediated instruction: A comparison of online and face-to-face collaboration. Educational Technology Research and Development, 56(2), 101-124. https://doi.org/10.1007/s11423-007-9050-9

Wamser, C. C. (2006). Peer-led team learning in organic chemistry: effects on student performance, success, and persistence in the course. Journal of Chemical Education, 83(10), 1562-1566. https://doi.org/10.1021/ed083p156

Wilson, S. B., \& Varma-Nelson, P. (2015). Small groups, significant impact: A review of peer-led team learning research with implications for stem education researchers and faculty. Journal of Chemical Education, 93(10), 1686-1702. https://doi.org/10.1021/acs.jchemed.5b00862 
Guden, J. M., \& Bellen, J. A.

14 Consortia Academia Publishing (A partner of Network of Professional Researchers and Educators) 